\title{
Gastrointestinal helminths in dog feces surrounding suburban areas of Lower Dir district, Pakistan: A public health threat
}

\author{
W. Khan ${ }^{a *}$ (D), N. N. Nisa , S. Ullah', S. Ahmad', S. A. Mehmood ${ }^{c}$, M. Khan ${ }^{a}$, S. Ahmad , \\ W. Alid, Hamid Ullah ${ }^{e}$ and Khurshaid Anwar ${ }^{f}$

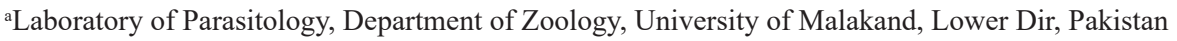

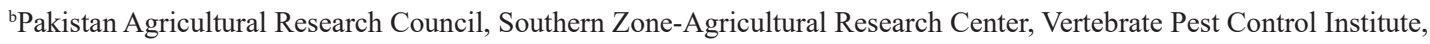 \\ University of Karachi, Karachi, Pakistan \\ ${ }^{c}$ Department of Zoology, University of Hazara, Mansehra, Pakistan \\ ${ }^{\mathrm{d}}$ Department of Biotechnology, University of Malakand, Lower Dir, Pakistan \\ ${ }^{e}$ Department of Zoology, University of Peshawar, Peshawar, Khyber-Pakhtunkhwa Pakistan \\ ${ }^{\mathrm{f}}$ Live Stock Research and Dairy Development Department, KP, Pakistan \\ *e-mail: walikhan.pk@gmail.com
}

Received: 16 August 2018 - Accepted: 25 March 2019 - Distributed: August 31, 2020

\begin{abstract}
Data on environmental contamination of the parasites of zoonotic importance is scarce in Pakistan. Soil contamination with feces of dogs hide infective stages of the parasite represents a health-risk to humans. This study was aimed to assess the eggs of gastrointestinal parasites of stray dogs and household dogs in lower Dir district, Pakistan with special consideration to those that can be spread to humans. One hundred and fifty two stool specimens from (stray dogs $=90$ and household dogs $=62$ ) were collected. The helminth eggs were processed by direct smear method and centrifugation techniques and identified by microscopic examination. Of the total examined $\operatorname{dogs} 26.8 \%(\mathrm{n}=41 / 152)$ were found to be infected with one or more intestinal parasites. The intestinal helminths detected were Dipylidium caninum $(\mathrm{n}=18,11.8 \%)$, followed by Toxocara canis $(\mathrm{n}=16,10.5 \%)$, Taenia spp., $(\mathrm{n}=10,6.57 \%)$ Ancylostoma caninum $(\mathrm{n}=6,3.94)$, Toxascaris spp., Capillaria spp., and Trichuris vulpis $(\mathrm{n}=2,1.31 \%$ each) in order of their prevalence. Pattern of infection revealed that $27(65.8 \%)$ dogs have single, 13(31.7\%) double and 1(2.43\%) triple infection. The stray dogs were highly infected $34.4 \%(n=31)$ than house hold dogs $16.1 \%(n=10)$. The prevalence of infection with intestinal parasites was significantly different among these two groups $(\mathrm{p}=0.0097)$. This study highlight a severe environmental contamination by frequent parasitic stages infectious to humans. There is a higher risk of zoonotic transmission from dogs which indicate an immediate need for the controlling of these parasites and educating the public to take wise action relating to the parasites and pets.
\end{abstract}

Keywords: contamination, diagnosis, environmental, parasitism, zoonosis.

\section{Helmintos gastrointestinais em fezes de cães que vivem em áreas suburbanas do distrito de Lower Dir, Paquistão: uma ameaça à saúde pública}

\begin{abstract}
Resumo
Dados sobre a contaminação ambiental dos parasitas de importância zoonótica são escassos no Paquistão. A contaminação do solo com fezes de cães, as quais escondem as fases infecciosas do parasita, representa um risco à saúde dos seres humanos. Este estudo teve como objetivo avaliar os ovos de parasitas gastrointestinais de cães de rua e domésticos no distrito de Lower Dir, no Paquistão, com especial atenção para aqueles que podem ser transmitidos aos seres humanos. Foram recolhidos 152 espécimes de fezes de cães, dos quais 90 eram de rua e 62 eram domésticos. Os ovos de helmintos foram processados por método de esfregaço direto e técnicas de centrifugação e identificados por exame microscópico. Do total de cães examinados, verificou-se que 26,8\% $(n=41 / 152)$ estavam infectados com um ou mais parasitas intestinais. Os helmintos intestinais detectados foram Dipylidium caninum $(\mathrm{n}=18 ; 11,8 \%)$, seguido por Toxocara canis $(\mathrm{n}=16 ; 10,5 \%)$, Taenia spp. $(\mathrm{n}=10 ; 6,57 \%)$, Ancylostoma caninum $(\mathrm{n}=6 ; 3,94 \%)$, Toxascaris spp., Capillaria spp. e Trichuris vulpis $(\mathrm{n}=2 ; 1,31 \%$ cada) em ordem de prevalência. O padrão de infecção revelou que 27 (65,8\%) cães tinham infecção simples, 13 (31,7\%), duplas, e 1 (2,43\%), tripla. Os cães de rua estavam altamente infectados $(34,4 \% ; n=31)$ do que os cães domésticos $(16,1 \% ; n=10)$. A prevalência de infecção por parasitas intestinais foi significativamente diferente entre esses dois grupos $(p=0,0097)$. Este estudo destaca uma grave contaminação ambiental por frequentes fases parasitárias infecciosas para humanos. Existe um risco maior de transmissão zoonótica de cães, o que indica uma necessidade imediata do controle desses parasitas, além de educar o público quanto à tomada de medidas relativas aos parasitas e aos animais de estimação.
\end{abstract}

Palavras-chave: contaminação, diagnóstico, meio ambiente, parasitismo, zoonose. 


\section{Introduction}

Dog plays an important role in the transmission of zoonotically important parasites to human beings. Dog feces are the main pollution source when not regularly removed. Furthermore, vehicular traffic, as well as the wind, can help in spreading pathogens present in dog feces, contaminating food which may later be a source of infection (Smith, 1995). Parasite eggs can also be carried into human houses if adhered to shoes or animals' paws. Additionally, arthropods and other environmental factors, as the rain, air and wind may also play a vital role in this context (Morey, 2006).

Environmental contamination with dog feces harboring various infective stages of parasites such as eggs, larvae or oocysts act as a leading source of infection to live-stock and human (Bentounsi et al., 2009). Hydatidosis and toxocariasis, are considered as serious public health concern (Alvarez-Rojas et al., 2014). Being a reservoir host for a large number of parasites dogs share these pathogens between pets and humans (Duscher et al., 2015). Human can be infected through the ingestion of eggs, cysts or oocysts via contaminated food-stuffs or water, hands, inhalation of dust, and/or by penetration of larvae through the skin (Lee et al., 2010).

Dogs are definitive hosts for quite a large number of parasites for which other animals may become intermediate hosts and some of the parasites like Giardia lamblia, Toxocara canis, Cryptosporidium spp, Ancylostoma duodenale, Echinococcus granulosus, Dipylidium caninum, and Toxoplasma gondii (Nicolle and Manceaux, 1908) can be transmitted to human from dogs (Overgaauw et al., 2009; Xhaxhiu et al., 2011). These diseases cause direct and indirect losses to the health of humans and their animals.

In Pakistan domestic dogs have got comparatively greater attention for deworming as compared to stray dogs. This lack of attention leave the stray dogs at higher risk of getting infected with parasites of great medical importance. Study conducted on dogs is almost always on domesticated ones and the results of these studies are biased as the stray dogs are not represented.

A small number of reports are available on the infection risk of dogs to humans living in rural and suburban areas in Pakistan. Most of these communities have a large number of free roaming domestic dogs with little access to veterinary care. These dogs have frequent contact with other animals, their faeces, and a variety of refuse and food-stuffs that contain zoonotic agents, which promotes infection with a variety of zoonotic agents and subsequent human exposure. The aim of this study was to evaluate the occurrence of zoonotic gastro-intestinal parasites of dogs from two breeds in lower Dir district Pakistan.

\section{Material and Methods}

Present research was carried out in suburban areas of district lower Dir, Khyber Pakhtunkhwa, Pakistan from March to August 2017. Lower Dir district is located $34.9161^{\circ} \mathrm{N}, 71.8097^{\circ} \mathrm{E}$

Faecal samples of stray dogs $(n=90)$ and house hold dogs $(n=62)$ were collected from walking areas of the animals around human populations. The collected samples were kept in sterilised plastic bottles and 10\% formalin was added just enough to dip the feces. All the samples were brought to Laboratory of Parasitology, Department of Zoology, University of Malakand, for parasitological assessment

The samples were first checked with naked eye for any adult stage of the parasites and then these were prepared for microscopic examination. A small portion of the sample was taken and a drop of liquid was added to it. For examining any cystic stage of a protozoan parasite the normal iodine solution was added while helminth eggs were generally observed in normal saline preparation. The slide was covered with cover slip and examined under the microscope. All the parasites found were identified through existing morphological keys. An animal was considered positive if only one parasite species was found in the fecal sample (Blagburn, 2014).

The data was analysed by applying the statistical software "Graph Pad Version 5". The p value less than 0.05 was considered to be statistically significant.

\section{Results}

Present study demonstrate the presence of seven helminth species in dogs of two breeds. The overall prevalence of infection with intestinal helminth parasites was $26.8 \%$ (Table 1 and 2). The most frequently observed intestinal helminth parasites were Dipylidium caninum (Linneus, 1758)13.3\%(n=12) and 9.67\% $(\mathrm{n}=6)$, Toxascaris canis $15.5 \%(\mathrm{n}=14)$ and $3.22 \%(\mathrm{n}=2)$, Taenia spp $11.1 \%$ $(\mathrm{n}=10)$ and $0 \%(\mathrm{n}=0)$, Ancylostoma caninum $4.44 \%(\mathrm{n}=4)$ and $3.22 \%(\mathrm{n}=2)$, Toxoascaris spp $2.22 \%(\mathrm{n}=2)$ and $0 \%$ $(\mathrm{n}=0)$, Capillaria $\operatorname{spp} 0 \%(\mathrm{n}=0)$ and $3.22 \%(\mathrm{n}=2)$, Trichuris vulpis $2.22 \%(\mathrm{n}=2)$ and $0 \%(\mathrm{n}=0)$ in stray dogs and house hold dogs respectively (Table 3 ). Eggs count per gram $($ mean $\pm \mathrm{SE})$ in feces of dogs have shown in Table 4.

A total of 152 ( $n=90$ from stray dogs and 62 from house hold dogs) faecal samples were examined. Out of the examined only $26.8 \%(n=41)$ were positive

Table 1. Prevalence of parasites found in dog fecal samples collected in lower Dir district, KPK, Pakistan.

\begin{tabular}{lccc}
\multicolumn{1}{c}{ Parameters } & Stray dogs & House hold dogs & Total (\%) \\
\hline Total samples examined & 90 & 62 & 152 \\
Total samples positive & $31(34.4 \%)$ & $10(16.1 \%)$ & $41(26.8)$ \\
Total samples negative & $59(65.5 \%)$ & $52(83.8 \%)$ & $111(73.0)$ \\
\hline
\end{tabular}


Table 2. Association of parasites: monoparasitism and polyparasitism among two breed of dogs (stray dogs and household dogs ( $n=$ number of dogs infected).

\begin{tabular}{|c|c|c|c|c|c|}
\hline $\begin{array}{l}\text { Type of } \\
\text { infection }\end{array}$ & No. of species & Species associated & $\begin{array}{c}\text { Stray } \\
\text { dogs }\end{array}$ & $\begin{array}{c}\text { House } \\
\text { hold dogs }\end{array}$ & Total \\
\hline \multirow[t]{5}{*}{ Mono-parasitism } & 1 species & Toxocara canis & 6 & 0 & 6 \\
\hline & & Capillaria spp. & 0 & 2 & 2 \\
\hline & & Ancylostoma caninum & 2 & 1 & 3 \\
\hline & & Dipylidium caninum & 6 & 5 & 11 \\
\hline & & Taenia spp. & 5 & 0 & 5 \\
\hline \multicolumn{3}{|c|}{ Total mono-parasitism } & 19 & 8 & 27 \\
\hline \multirow[t]{9}{*}{ Poly-parasitism } & 2 species & T. canis + A.caninum & 2 & 1 & 3 \\
\hline & & Toxascaris canis + Dipylidium caninum & 3 & 1 & 4 \\
\hline & & Trichuris vulpis+Taenia spp. & 2 & 0 & 2 \\
\hline & & Toxosscaris + Taenia $\mathrm{spp}$ & 2 & 0 & 2 \\
\hline & & Toxocara canis + D.caninum & 2 & 0 & 2 \\
\hline & & & 11 & 2 & 13 \\
\hline & 3 species & & & & \\
\hline & & Toxocara canis + D.caninum + Taenia spp. & 1 & 0 & 1 \\
\hline & & & 1 & $\mathbf{0}$ & 1 \\
\hline \multicolumn{3}{|c|}{ Total poly-parasitism } & 12 & 2 & 14 \\
\hline \multicolumn{3}{|c|}{ Total of infected dogs } & 31 & 10 & 41 \\
\hline
\end{tabular}

Table 3. Prevalence of parasites in faeces of stray dogs and house hold dogs in Lower Dir district, KPK, Pakistan.

\begin{tabular}{lccc}
\hline \multicolumn{1}{c}{ Parasites } & Stray dogs & House hold dogs & Total (\%) \\
\hline Dipylidium caninum & $12(13.3)$ & $6(9.67)$ & $18(11.8)$ \\
Toxocara canis & $14(15.5)$ & $2(3.22)$ & $16(10.5)$ \\
Taenia spp. & $10(11.1)$ & 0 & $10(6.57)$ \\
Ancylostoma caninum & $4(4.44)$ & $2(3.22)$ & $6(3.94)$ \\
Toxoascaris spp & $2(2.22)$ & 0 & $2(1.31)$ \\
Capillaria spp. & 0 & $2(3.22)$ & $2(1.31)$ \\
Trichuris vulpis & $2(2.22)$ & 0 & $2(1.31)$ \\
Total infected & $44(48.8)$ & $12(19.3)$ & $56(36.8)$ \\
Total examined & 90 & 62 & 152 \\
\hline
\end{tabular}

Table 4. Eggs count per gram (mean $\pm \mathrm{SE}$ ) in feces of dogs in lower Dir district, KPK, Pakistan.

\begin{tabular}{lccc}
\hline \multicolumn{1}{c}{ Parasites } & Stray dogs & House hold dogs & Total (\%) \\
\hline Dipylidium caninum & $6.75 \pm 3.40$ & $17.1 \pm 5.30$ & $25.3 \pm 10.6$ \\
Toxocara canis & $11.7 \pm 6.41$ & $20.5 \pm 16.2$ & $25.8 \pm 12.7$ \\
Taenia spp. & $19.2 \pm 7.0$ & 00 & $22.8 \pm 8.28$ \\
Ancylostoma caninum & $23.5 \pm 7.98$ & $32 \pm 18.3$ & $17.6 \pm 5.16$ \\
Toxoascaris spp & $50.5 \pm 23.3$ & 0 & $14 \pm 0$ \\
Capillaria spp. & 00 & $13.5 \pm 4.94$ & $18.5 \pm 6.3$ \\
Trichuris vulpis & $30.5 \pm 4.94$ & 00 & $15.2 \pm 7.77$ \\
\hline
\end{tabular}

for the presence of gastro-intestinal parasitic forms. The prevalence of parasites found in two breeds of dogs were $34.4 \%$ in stray dogs and $16.1 \%$ in house hold dogs respectively (Table 1 ).

Regarding the number of parasites species detected in each sample, 27 dogs (17.7\%) were infected with a single parasite species, thirteen $(8.55 \%)$ were infected with two parasite species and only one $\operatorname{dog}(0.65 \%)$ was infected with three parasite species (Table 2).
Seven species of helminth parasites were detected, including 5 species of nematodes and 2 species of cestodes. Stray dogs were found highly infected than house hold dogs. D.caninum, T.canis, Taenia spp., Ancylostoma caninum, Toxascaris spp., Capillaria spp., and T,vulpis were investigated (Table 3 ). All the reported species were found in stray dog except Capillaria spp., similarly, Taenia spp., Toxascaris spp., and T. vulpis were not found in house hold dogs (Table 3 ). 
Table 5. Prevalence (\%) of intestinal parasites of dogs relative to host age, sex and breed.

\begin{tabular}{|c|c|c|c|c|}
\hline Category & $\begin{array}{c}\text { Number } \\
\text { examined }\end{array}$ & Number infected & $\%$ & $P$ value (at $95 \% \mathrm{CI}$ ) \\
\hline \multicolumn{5}{|l|}{ Stray dogs } \\
\hline \multicolumn{5}{|l|}{ Age } \\
\hline Adults & 47 & 31 & 34.4 & $0.1301(-16.67$ to 62.67$)$ \\
\hline Sub-adults & 43 & 13 & 14.4 & \\
\hline Total & 90 & 44 & 48.8 & \\
\hline \multicolumn{5}{|l|}{ Sex } \\
\hline Male & 55 & 29 & 32.2 & $0.2002(-29.52$ to 75.52$)$ \\
\hline Female & 35 & 15 & 16.6 & \\
\hline Total & 90 & 44 & & \\
\hline \multicolumn{5}{|l|}{ House hold dogs } \\
\hline \multicolumn{5}{|l|}{ Age } \\
\hline Adults & 42 & 8 & 12.9 & $0.1596(-24.06$ to 74.06$)$ \\
\hline Sub-adults & 20 & 3 & 4.83 & \\
\hline total & 62 & 11 & 17.7 & \\
\hline \multicolumn{5}{|l|}{ Sex } \\
\hline Male & 37 & 7 & 11.2 & $0.0544(-1.174$ to 51.17$)$ \\
\hline Female & 25 & 4 & 6.45 & \\
\hline Total & 62 & 11 & & \\
\hline
\end{tabular}

CI stand for confidence interval.

Older dogs were more infected than younger ones. The male dogs in both the breeds were more infected than females. No significant difference $(\mathrm{p}<0.05)$ for ages, sex and breeds (Table 5).

\section{Discussion}

Information regarding prevalence of gastro-intestinal parasite of dog and their environmental contamination is very limited in Pakistan. Stray dogs were observed more parasitized $(34.4 \%)$ than house hold dogs (16.1\%). Parasitic contamination levels are comparable with earlier studies conducted on dog faecal samples in countries such as: Nigeria 33.9\% (Ogbaje et al., 2015); Poland 37.4\% (Szwabe and Błaszkowska, 2017). In different parts of the world the prevalence rate was higher than the present study as: Cuba 44.3\% (Puebla et al., 2015); Nepal 46.7\% (Satyal et al., 2013); Kandy district 90\% (Perera et al., 2013). The prevalence documented in Mexico 26.5\% (Chable et al., 2015; Bangladesh 22.4\% (Mahmud et al., 2014; Iran 19.1\% (Kohansal et al., 2017) was lower than all other studies conducted. Helminths reported in this study may be transmittable through the consumption of uncooked vegetables irrigated by water polluted by human feces and/or ingestion of faecally contaminated soil (Adanir and Tascl, 2013).

Dipylidium caninum is also called the double pore tapeworm. This tapeworm was the most frequent parasite $(11.8 \%)$ living in the intestines of stray dogs as well as in house hold dogs in present study. Our findings were matching to the study conducted in Spain 13.2\% (Martinez-Moreno et al., 2007). The highest prevalence $73.3 \%$ of this nematode was reported in Australia (Jenkins and Andrew, 1993) and Iran $64.4 \%$ (Sowemimo and Asaolu, 2008) while the lowest rate of prevalence was noted in Nigeria $0.2 \%$ (Sowemimo and Asaolu, 2008); Hungary 1\% (Fok et al., 2001); Australia 0.2\% (Bugg et al., 1999); Spain 2.5\% (Causape et al., 1996); Venezuela 2.37\% (Ramirez-Barrios et al., 2004). Dipylidium caninum has also been reported by Wong, (Wong, 1955) while (Narasimham et al., 2013) reported this infection in a male child for the first time in India.

Toxocara canis is also called the dog round worm has world wide in distribution with great zoonotic importance. Toxocara canis (10.5\%)was the second most frequent parasite species in current study. The prevelence was meet with studies conducted in Tanzania 13.7\% (Swai et al., 2010); Nigeria 9.6\% (Sowemimo and Asaolu, 2008). The highest prevalence of this nematode was reported in Canada $43.5 \%$ (Seah et al., 1975); Hungary 24.7\% (Fok et al., 2001); Spain 29.2\% (Martinez-moreno et al., 2007); Galapagos Islands $16.5 \%$ (Gingrich et al., 2010). This nematode was reported in low rate of prevalence in Australia 1.7\% (Bugg et al., 1999); Belgium 4.6\% (Claerebout et al., 2009); Spain $3.7 \%$ (Causape et al., 1996). Toxocariasis is prevalent in tropical and developing countries of the world (Glickman and Magnaval, 1993). The life cycle of this nematode is completed in dog. Humans acquire infection as accidental hosts. Toxocariasis occurs primarily in young children, who get Toxocara eggs through contact with soil contaminated by the faeces of dogs that carry the parasite. Occasionally, adults who eat clay become infected. After the eggs are swallowed, larvae hatch in the intestine wall and are spread through the blood stream and causes visceral larva migrans or toxocariasis (Dickson, 2003). 
Taenia sp. (6.57\%) the third most frequently prevalent parasite in present study. This finding is relatively matching with the study conducted in Spain 11\% (Martinez-Moreno). However this cestode is relatively low in prevalence in other parts of the world as in Tanzania $0.4 \%$ (Swai et al., 2010); Hungary, 2.8\% (Fok et al., 2001); Belgium 0.2\% (Claerebout et al., 2009); Spain 2.5 (Causape et al., 1996). Taenia spp is one of the meat born pathogenic helminth parasites of human in origin. Taenia saginata has also been reported to be infected human in Pakistan as $0.4 \%$ Arshad et al. (2019) Karachi; 9.70\% Khan et al. (2019) Swat; $8.98 \%$ Khan et al. (2017) Swat. This disease causes heavy economic losses with enormous health and social implications in endemic communities of the world.

Ancylostoma caninum is the most common and pathogenically important hookworm of dog. This was 3.94\% in present study findings. This finding was meet with the findings conducted in Spain 6.2\% (Causape et al., 1996). Higher prevalence of this nematode was in Australia 100\% (Jenkins and Andrew, 1993; Galapagos 57.7\% (Gingrich et al., 2010); Tanzania 57\% (Swai et al., 2010); Australi 22.1\% (Bugg et al., 1999); Nigeria 17.9\% (Sowemimo and Asaolu, 2008). The lowest rate of prevalence was documented in Hungary $8.1 \%$ (Fok et al., 2001).

Toxascaris spp and Capillaria spp each were $1.3 \%$ in present findings. Spain $2.5 \%$ These parasites were reported $2.5 \%$ and $7.3 \%$ by (Causape et al., 1996) in Spain and (Fok et al., 2001) in Hungary respectively. Trichuris vulpis $1.3 \%$ in present investigation. Canada $0.7 \%$ (Gaunt and Carr, 2011); Nigeria 0.5\% (Sowemimo and Asaolu, 2008); Spain 1.66\% (Martiz-Moreno); Australia 80\% (Jenkins and Andrew, 1993); Spain 3.7\% (Causape et al., 1996); United states 1.2\% (Little et al., 2009).

Present study demonstrated $65.8 \%$ as single infetion, this ratio agrees with the studies conducted in Venezuela 68.3\% (Traversa et al., 2009); Tanzania 73.8\% (SWAI et al., 2010); Canada $54.9 \%$ (Seah et al., 1975); Hungary $50 \%$ (Fok et al., 2001). The study conducted in Australia was showing the low rate of single infection which was 19\% (Bugg et al., 1999). Of the examined samples 31.7\% were found infected with 2 species of parsites in present resaerch. This was agreed with the studies conducted in Canada 30.9\% (Seah et al., 1975); Hungary 24\% (Fok et al., 2001). Findings of all other studies showed low rate of infection with 2 species of parasites in the dogs studies as Tanzania $12.4 \%$ (Swai et al., 2010); Galapagos Islands $11.3 \%$ (Gingrich et al., 2010); Australia 6.4\% (Bugg et al., 1999). The percent of dogs infected with 3 species of parasites were $2.43 \%$ in present investigation which was matching with the studies conducted in Australia 2.3\% (Bugg et al., 1999); Galapagos 2.1\% (Gingrich et al., 2010); the high prevalence of infection in the context of 3 species infection was in Hungary 26\% (Fok et al., 2001); Canada $12.3 \%$ (Seah et al., 1975) while the lowest rate was noted in Tanzania $0.4 \%$ (Swai et al., 2010).

Differences in the results of all these surveys might be due to geographical location, environmental factors, sample size, diagnostic procedures and other stress factors involved in parasite transmission. Higher prevalence rate in older dogs might be due to the freely mobile nature of the animal and might also be due to the low level of immunity of older dogs than young pups.

In conclusion, dog represent a potential public health risk, transmit infective form of parasites to humans. This study calls for the fact that stray dogs play a key role in environmental contamination than house hold dogs. Close contact of humans with untreated dogs, no deworming practices and the favourable climatic conditions are the survival factors of infective stages of dog helminth parasites. The general public and dog oweners should be aware on the presence of dog parasites in their surroundings.

\section{References}

ADANIR, R. and TASCL, F., 2013. Prevalence of helminth eggs in raw vegetables consumed in Burdur, Turkey. Food Control, vol. 31, no. 2, pp. 482-484. http://dx.doi.org/10.1016/j. foodcont.2012.10.032.

ALVAREZ-ROJAS, C.A., ROMIG, T. and LIGHTOWLERS, M.W., 2014. Echinococcus granulosus sensu lato genotypes infecting humans- review of current knowledge. International Journal for Parasitology, vol. 44, no. 1, pp. 9-18. http://dx.doi. org/10.1016/j.ijpara.2013.08.008. PMid:24269720.

ARSHAD, A., KHATOON, N., WARIND, J.A., KHAN, A., WAHEED, A. and KHAN, W., 2019. The prevalence of human intestinal protozoal and helminthic infection in Karachi. International Journal of Biology and Biotechnology, vol. 16, no. 2, pp. 319-323.

BENTOUNSI, B., MERADI, S., AYACHI, A. and CABARET, J., 2009. Cestodes of untreated large stray dog populations in Algeria: a reservoir for herbivore and human parasitic diseases. Open Veterinary Science Journal, vol. 3, no. 1, pp. 64-67. http:// dx.doi.org/10.2174/1874318809003010064.

BLAGBURN, B., 2014. Diagnostic manual on internal parasites of dogs and cats. Auburn: College of Veterinary Medicine Auburn University.

BUGG, R.J., ROBERTSON, I.D., ELLIOT, A.D. and THOMPSON, R.C.A., 1999. Gastrointestinal parasites of urban dogs in Perth, Western Australia. Veterinary Journal (London, England), vol. 157, no. 3, pp. 295-301. http://dx.doi.org/10.1053/tvj1.1998.0327. PMid:10328840.

CAUSAPE, A.C., QUILEZ, J., SANCHEZ-ACEDO, C. and DEL CACHO, E., 1996. Prevalence of intestinal parasites, including Cryptospo- ridium parvum, in dogs in Zaragoza city, Spain. Veterinary Parasitology, vol. 67, no. 3-4, pp. 161-167. http://dx.doi.org/10.1016/S0304-4017(96)01033-3. PMid:9017864.

CHABLÉ, T., HERRERA, R.A.G., HERNÁNDEZ, M.H., TORRES, J.A.P., ROBERTOS, N.F.O., BLITVICH, B.J., BAAK-BAAK, C.M., GARCÍA-REJÓN, J.E. and MACHAINWILIAMS, C.I., 2015. Prevalence of gastrointestinal parasites in domestic dogs in Tabasco, southeastern Mexico. Revista Brasileira de Parasitologia Veterinária, vol. 24, no. 4, pp. 432-437. http:// dx.doi.org/10.1590/S1984-29612015077.

CLAEREBOUT, E., CASAERT, S., DALEMANS, A.C., DE WILDE, N., LEVECKE, B., VERCRUYSSE, J. and GEURDEN, T., 2009. Giardia and other intestinal parasites in different dog populations in Northern Belgium. Veterinary Parasitology, vol. 161, 
no. 1-2, pp. 41-46. http://dx.doi.org/10.1016/j.vetpar.2008.11.024. PMid:19155136.

DICKSON, D., 2003. Toxocariasis: clinical aspects, epidemiology, medical ecology, and molecular aspects. Clinical Microbiology Reviews, vol. 16, no. 2, pp. 265-272. PMid:12692098.

DUSCHER, G.G., LESCHNIK, M., FUEHRER, H.P. and JOACHIM, A., 2015. Wildlife reservoirs for vector-borne canine, feline and zoonotic infections in Austria. International Journal for Parasitology. Parasites and Wildlife, vol. 4, no. 1, pp. 88-96. http://dx.doi.org/10.1016/j.ijppaw.2014.12.001. PMid:25830102.

FOK, E., SZATMARI, V., BUSAK, K. and ROZGONYI, F., 2001. Epidemiology: prevalence of intestinal parasites in dogs in some urban and rural areas of Hungary. The Veterinary Quarterly, vol. 23, no. 2, pp. 96-98. http://dx.doi.org/10.1080/01652176.20 01.9695091. PMid:11361108.

GAUNT, M.C. and CARR, A.P., 2011. A survey of intestinal parasites in dogs from Saskatoon, Saskatchewan. The Canadian Veterinary Journal. La Revue Veterinaire Canadienne, vol. 52, no. 5, pp. 497-500. PMid:22043068.

GINGRICH, E.N., SCORZA, A.V., CLIFFORD, E.L., OLEAPOPELKA, F.J. and LAPPIN, M.R., 2010. Intestinal parasites of dogs on the Galapagos Islands. Veterinary Parasitology, vol. 169, no. 3-4, pp. 404-407. http://dx.doi.org/10.1016/j.vetpar.2010.01.018. PMid:20176441.

GLICKMAN, L.T. and MAGNAVAL, J.F., 1993. Zoonotic roundworm infections. Infectious Disease Clinics of North America, vol. 7, no. 3, pp. 717-732. PMid:8254168.

JENKINS, D. and ANDREW, P., 1993. Intestinal parasites in dogs from an Aboriginal community in New South Wales. Australian Veterinary Journal, vol. 70, no. 3, pp. 115-116. http:// dx.doi.org/10.1111/j.1751-0813.1993.tb03292.x. PMid:8476358.

KHAN, W., KHAN, N.I., FARYAL, S.N.B. and BEGUM, N., 2019. Prevalence of intestinal parasitic infection among drug addicts in district swat, Khyber Pakhtunkhwa, Pakistan. Iranian Journal of Parasitology, vol. 14, no. 2, pp. 359-361.

KHAN, W., NOOR-UN-NISA and KHAN, A., 2017. Prevalence and risk factors associated with intestinal parasitic infections among food handlers of swat, Khyber Pakhtunkhwa, Pakistan. Journal of Food and Nutrition Research, vol. 5, no. 5, pp. 331336. http://dx.doi.org/10.12691/jfnr-5-5-7.

KOHANSAL, M.H., FAZAELI, A., NOURIAN, A., HANILOO, A. and KAMALI, K., 2017. Dogs' gastrointestinal parasites and their association with public health in Iran. Journal of Veterinary Research (Pulawy), vol. 61, no. 2, pp. 189-195. http://dx.doi. org/10.1515/jvetres-2017-0024.

LEE, A.C., MONTGOMERY, S.P., THEIS, J.H., BLAGBURN, B.L. and EBERHARD, M.L., 2010. Public health issues concerning the widespread distribution of canine heartworm disease. Trends in Parasitology, vol. 26, no. 4, pp. 168-173. http://dx.doi. org/10.1016/j.pt.2010.01.003. PMid:20181530.

LITTLE, S.E., JOHNSON, E.M., LEWIS, D., JAKLITSCH, R.P., PAYTON, M.E., BLAGBURN, B.L., BOWMAN, D.D., MOROFF, S., TAMS, T., RICH, L. and AUCOIN, D., 2009. Prevalence of intestinal parasites in pet dogs in the United States. Veterinary Parasitology, vol. 166, no. 1-2, pp. 144-152. http:// dx.doi.org/10.1016/j.vetpar.2009.07.044. PMid:19716659.

MAHMUD, M.A.A., BELAL, S.M.S.H. and UDDIN, F.M.J., 2014. Prevalence of protozoan diseases in pet dogs at district veterinary hospital, Sirajganj, Bangladesh. Bangladesh Journal of Veterinary Medicine, 12(2):191-196. http://dx.doi.org/10.3329/ bjvm.v12i2.21290.

MARTINEZ-MORENO, F.J., HERNÁNDEZ, S., LÓPEZCOBOS, E., BECERRA, C., ACOSTA, I. and MARTINEZMORENO, A., 2007. Estimation of canine intestinal parasites in Cordoba (Spain) and their risk to public health. Veterinary Parasitology, vol. 143, no. 1, pp. 7-13. http://dx.doi.org/10.1016/j. vetpar.2006.08.004. PMid:16971046.

MOREY, D.F., 2006. Burying key evidence: the social bond between dogs and people. Journal of Archaeological Science, vol. 33, no. 2, pp. 158-175. http://dx.doi.org/10.1016/j.jas.2005.07.009.

NARASIMHAM, M.V., PANDA, P., MOHANTY, I., SAHU, S., PADHI, S. and DASH, M., 2013. Dipylidium caninum infection in a child: a rare case report. Indian Journal of Medical Microbiology, vol. 31, no. 1, pp. 82-84. http://dx.doi. org/10.4103/0255-0857.108738. PMid:23508438.

OGBAJE, C.I., OFUKWU, R.A. and AJOGI, I.A., 2015. Zoonotic gastrointestinal parasite burden of local dogs in Zaria, Northern Nigeria: implications for human health. Internation Journal of One Health, vol. 1, pp. 32-36. http://dx.doi.org/10.14202/ IJOH.2015.32-36.

OVERGAAUW, P.A., VAN ZUTPHEN, L., HOEK, D., YAYA, F.O., ROELFSEMA, J., PINELLI, E., VAN KNAPEN, F. and KORTBEEK, L.M., 2009. Zoonotic parasites in fecal samples and fur from dogs and cats in The Netherlands. Veterinary Parasitology, vol. 163, no. 1-2, pp. 115-122. http://dx.doi. org/10.1016/j.vetpar.2009.03.044. PMid:19398275.

PERERA, P.K., RAJAPAKSE, R.P.V.J. and RAJAKARUNA, R.S., 2013. AND RAJAKARUNA RS. 2013. Gastrointestinal parasites of dogs in Hantana area in the Kandy District. Journal of the National Science Foundation of Sri Lanka, vol. 41, no. 2, pp. 81-91. http://dx.doi.org/10.4038/jnsfsr.v41i2.5703.

PUEBLA, L.E.J., NUNEZ, F.A., RIVERO, L.R., HERNANDEZ, Y.R., GARCIA, I.S. and MILLAN, I.A., 2015. Prevalence of intestinal parasites in dogs from Municipality La Lisa, Havana, Cuba. Journal of Veterinary Science and Technology, vol. 6, pp. 250. http://dx.doi.org/10.4172/2157-7579.1000250.

RAMÍREZ-BARRIOS, R.A., BARBOZA-MENA, G., MUÑOZ, J., ANGULO-CUBILLÁN, F., HERNÁNDEZ, E., GONZÁLEZ, F. and ESCALONA, F., 2004. Prevalence of intestinal parasites in dogs under veterinary care in Maracaibo, Venezuela. Veterinary Parasitology, vol. 121, no. 1-2, pp. 11-20. http://dx.doi.org/10.1016/j.vetpar.2004.02.024. PMid:15110399.

SATYAL, R.C., MANANDHAR, S., DHAKAL, S., MAHATO, S., CHAULAGAIN, S., GHIMIRE, L. and PANDEYA, Y.R., 2013. Prevalence of gastrointestinal zoonotic helminths in dogs of Kathmandu, Nepal. International Journal of Infection and Microbiology, vol. 2, no. 3, pp. 91-94. https://doi.org/10.3126/ ijim.v2i3.8211.

SEAH, S., HUCAL, G. and LAW, C., 1975. Dogs and intestinal parasites: a public health problem. Canadian Medical Association Journal, vol. 112, no. 10, pp. 1191-1194. PMid:1125888.

SMITH, R.D., 1995. Veterinary clinical epidemiology. Boca Raton: CRC Press.

SOWEMIMO, O. and ASAOLU, S., 2008. Epidemiology of intestinal helminth parasites of dogs in Ibadan, Nigeria. Journal of Helminthology, vol. 82, no. 1, pp. 89-93. http://dx.doi.org/10.1017/ S0022149X07875924. PMid:18053301. 
SWAI, E.S., KAAYA, E.J., MSHANGA, D.A. and MBISE, E.W., 2010. A survey on gastro-intestinal parasites of nondescript dogs in and around Arusha Municipality, Tanzania. International Journal of Animal and Veterinary Advances, vol. 3, no. 2, pp. 63-67.

SZWABE, K. and BŁASZKOWSKA, J., 2017. Stray dogs and cats as potential sources of soil contamination with zoonotic parasites. Annals of Agricultural and Environmental Medicine, vol. 24 , no. 1 , pp. 39-43.

TRAVERSA, D., DI CESARE, A., MILILlo, P., IORIO, R. and OTRANTO, D., 2009. Infection by Eucoleus aerophilus in dogs and cats: is another extra-intestinal parasitic nematode of pets emerging in Italy? Research in Veterinary Science, vol. 87, no. 2, pp. 270-272. http://dx.doi.org/10.1016/j.rvsc.2009.02.006. PMid:19298989.

WONG, M.H., 1955. Multiple infestation with Dipylidium caninum in an infant. Canadian Medical Association Journal, vol. 72, no. 6, pp. 453-455. PMid:14352116.

XHAXHIU, D., KUSI, I., RAPTI, D., KONDI, E., POSTOLI, R., RINALDI, L., DIMITROVA, Z.M., VISSER, M., KNAUS, M. and REHBEIN, S., 2011. Principal intestinal parasites of dogs in Tirana, Albania. Parasitology Research, vol. 108, no. 2, pp. 341-353. http://dx.doi.org/10.1007/s00436-010-2067-8. PMid:20878182. 